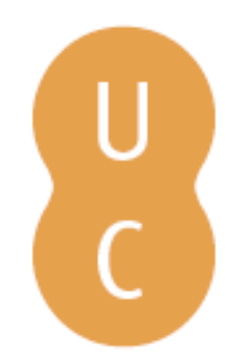

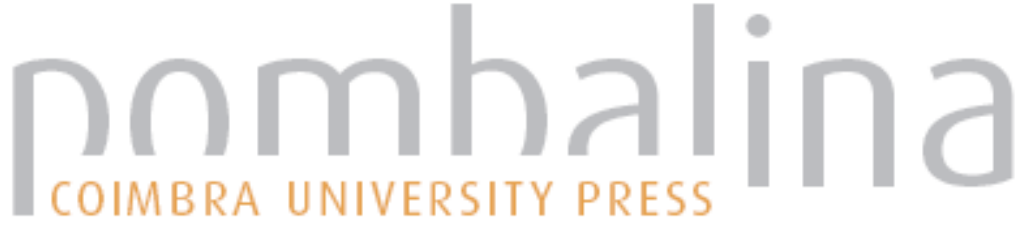

\section{A criação da imagem empresarial através da publicidade}

\author{
Autor(es): $\quad$ Mourão, Alda
}

Publicado por: Imprensa da Universidade de Coimbra

URL

persistente: URI:http://hdl.handle.net/10316.2/31622

DOI: $\quad$ DOI:http://dx.doi.org/10.14195/978-989-26-0199-1_22

Accessed : $\quad$ 26-Apr-2023 12:06:05

A navegação consulta e descarregamento dos títulos inseridos nas Bibliotecas Digitais UC Digitalis, UC Pombalina e UC Impactum, pressupõem a aceitação plena e sem reservas dos Termos e Condições de Uso destas Bibliotecas Digitais, disponíveis em https://digitalis.uc.pt/pt-pt/termos.

Conforme exposto nos referidos Termos e Condições de Uso, o descarregamento de títulos de acesso restrito requer uma licença válida de autorização devendo o utilizador aceder ao(s) documento(s) a partir de um endereço de IP da instituição detentora da supramencionada licença.

Ao utilizador é apenas permitido o descarregamento para uso pessoal, pelo que o emprego do(s) título(s) descarregado(s) para outro fim, designadamente comercial, carece de autorização do respetivo autor ou editor da obra.

Na medida em que todas as obras da UC Digitalis se encontram protegidas pelo Código do Direito de Autor e Direitos Conexos e demais legislação aplicável, toda a cópia, parcial ou total, deste documento, nos casos em que é legalmente admitida, deverá conter ou fazer-se acompanhar por este aviso.

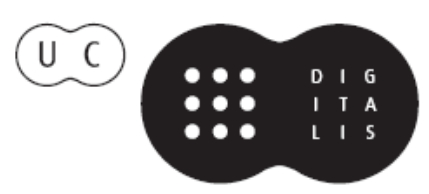


Maria Manuela Tavares Ribeiro

Coordenação

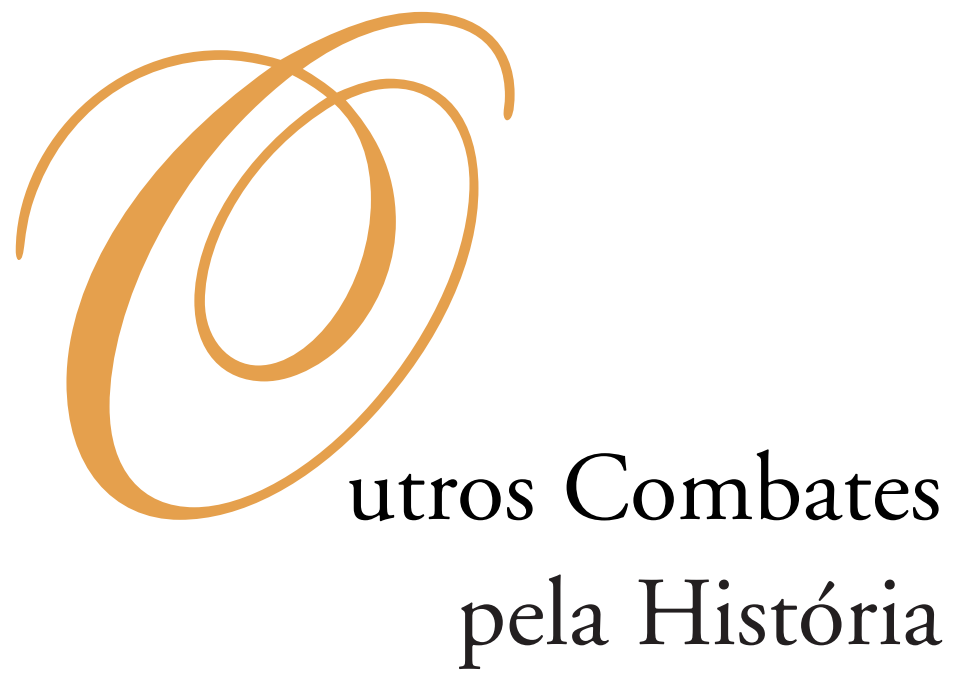




\section{COORDENAÇĀO EDITORIAL}

Imprensa da Universidade de Coimbra

Email: imprensauc@ci.uc.pt

URL: http://www.uc.pt/imprensa_uc

Vendas online: http://livrariadaimprensa.com

\section{CONCEPÇÃO GRÁFICA}

António Barros

\section{ORgANIZAÇĀO DOS TEXTOS}

Isabel Maria Luciano

Marlene Taveira

PRÉ-IMPRESSÃO

António Resende

Imprensa da Universidade de Coimbra

EXECUÇÃO GRÁFICA

SerSilito • Maia

ISBN

978-989-26-0041-3

DEPósito LEGAL

OBRA PUBLICADA COM O APOIO DE:

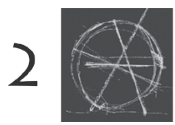

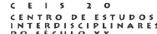

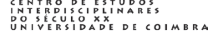

FCT Fundação para a Ciência e a Tecnologia

MINISTÉRIO DA CIÊNCIA, TECNOLOGIA E ENSINO SUPERIOR Portugal

Programa Operacional Ciência, Tecnologia, INOVAÇĀo DO QUADRo COMUNITÁRIO DE APOIO III

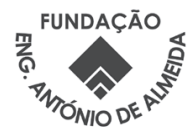

C JULHO 2010, IMPRENSA DA UNIVERSIDADE DE COIMBRA 
Maria Manuela Tavares Ribeiro

Coordenação

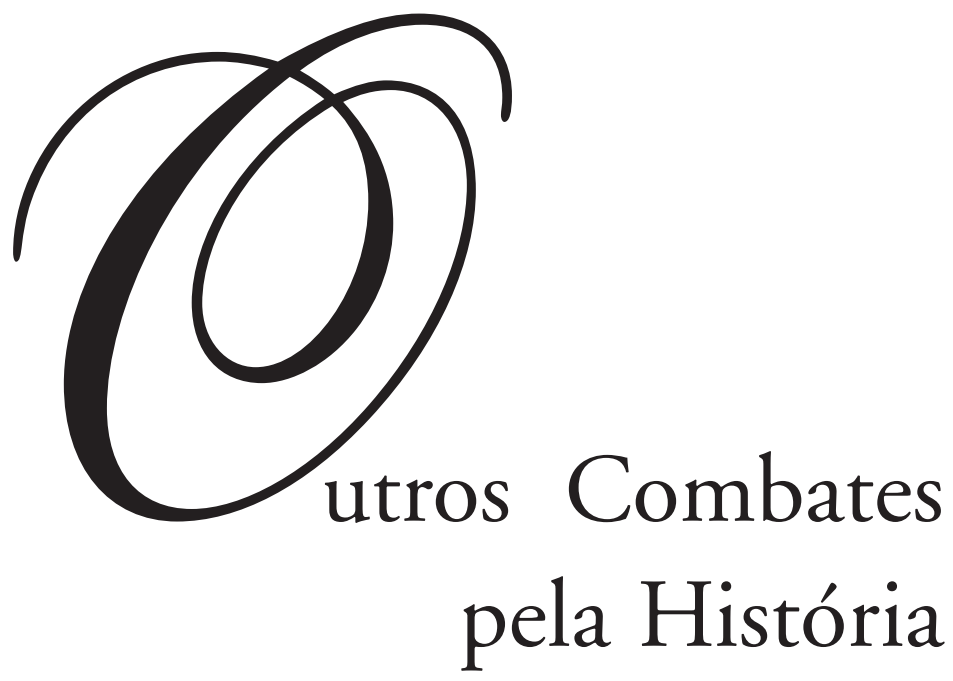

- colmbra 2010 
História e Organizaçôes

ECONÓMICAS E SOCIAIS 


\section{Alda Mourão}

\section{A CRIAÇÃO DA IMAGEM EMPRESARIAL ATRAVÉS DA PUBLICIDADE}

\section{História empresarial como área de investigação}

Em 2004, a revista Estudos do Século XX, uma publicação anual do CEIS20, foi dedicada à temática «Empresas e Empresários» ${ }^{1}$. Reuniram-se investigadores nacionais e estrangeiros para reflectirem sobre temáticas que apontavam para a diversidade de abordagens que esta área historiográfica vem albergando. Procedeu-se, então, a uma forma de balanço do caminho que vinha a trilhar a história empresarial, particularmente em Portugal, pelas reflexões de J. M. Amado Mendes e Carlos Bastien ${ }^{2}$, mas também em Espanha, através do estudo-síntese de Eloy Fernández Clemente. Posteriormente, a propósito de eventos científicos, de efemérides comemorativas ou do interesse académico, continuou-se a assistir a manifestações da vitalidade desta área historiográfica, entre nós.

O percurso traçado não esconde que a história empresarial ainda é uma área de investigação recente em Portugal. Assume, como outras, um carácter interdisciplinar, obrigando ao recurso de saberes sociais que se cruzam nos campos conceptuais e metodológicos. A partir dela, novos conhecimentos se têm revelado, no que respeita à história contemporânea, nomeadamente, os que giram em torno da organização de mercados, dos modelos de industrialização, da construção de elites locais e nacionais, entre outros.

Novas temáticas têm emergido, na sequência, não só da actividade dos investigadores que se dedicam à história empresarial, mas também da forma como têm vindo

${ }^{1}$ De maior vulto, para trás, em 2002, o Encontro Anual da Associação de História Económica e Social, realizado em Aveiro, tinha sido dedicado à temática "Empresa e instituições em perspectiva histórica».

2 Carlos Bastien (2004) - "A história empresarial em Portugal: um balanço da conjuntura teórica», Estudos do Século XX, n. ${ }^{\circ}$ 4, «Empresas e Empresários», CEIS20, Coimbra, pp. 41-58. José M. Amado Mendes "Elite empresarial e História das empresas: em busca de uma imagem de marca, 1924-2003", Estudos do Século XX, n. ${ }^{\circ}$, «Empresas e Empresários», CEIS20, Coimbra, pp. 17-39. José M. Amado Mendes é, ainda, autor de um largo número de outros estudos sobre esta mesma temática, quer sob o ponto de vista da história empresarial, propriamente dita, quer sobre o seu posicionamento na História Económica e Social. 
a evoluir os conceitos de "empresário» e de «empresa» ${ }^{3}$. O desenvolvimento da tecnologia e da ciência, postas ao serviço da formação do novo empresário, acompanha uma nova fase deste percurso evolutivo. Tal é a função que Drucker (1997: 30) atribui, por exemplo, à Gestão. A empresa passou a ser definida como "grupo humano com objectivos explícitos, que funciona segundo regras especificas, estabelece entre si um certo grau de interacções, distribui funçôes entre os membros e cria uma identificação de todos com um ideal e com metas partilhadas, surgindo um sentimento de pertença a uma unidade colectiva» ${ }^{4}$. Ao ser encarada como uma organização complexa que sintetiza conhecimentos, culturas e valores, a empresa aproximou-se da realidade que representa. Desenvolveu-se o quadro teórico, influenciado por Schumpeter e por Arthur Cole, que concedera as dimensões sociais e culturais à empresa e ao empresário. No sentido de dar resposta aos novos desafios científicos, novas fontes documentais têm vindo a ser consideradas e exploradas.

A história empresarial tem cumprido, ainda, a função de valorizar a tradição e o prestígio das organizaçôes a que se tem dedicado. Tem permitido analisar a «história de vida» da empresa, na forma como ela evoluiu internamente e como, externamente, se deu a conhecer. Para tanto, foi necessário analisar estratégias adoptadas para consolidar e divulgar o bom nome que se pretendia.

\section{Criação da imagem empresarial}

Actualmente, há todo um conjunto de disciplinas que centralizam o seu interesse científico na actividade empresarial. A Gestão, a Comunicação, as Relações Públicas, a Sociologia das Organizações, o Marketing, a Publicidade são disso exemplo. Todas elas apresentam contributos teóricos para a História Empresarial.

O que nos ensinam? Por exemplo, que empresas e empresários, enquanto fracçōes de uma totalidade, se tornaram personagens sociais e económicas, com personalidade própria $^{5}$, comportamentos e ideologias. A empresa, entendida como um todo, detém valores, crenças e maneiras de actuar que definem o seu comportamento; compōe uma identidade. A construção da identidade empresarial parece residir, exclusivamente, na própria empresa. Para alguns autores, distancia-se da imagem que se deve construir

\footnotetext{
3 A História Empresarial tem estado atenta ao quadro teórico desenvolvido por outras disciplinas como a Gestão, a Comunicação (principalmente Organizacional), as Relaçōes Públicas, a Sociologia das Organizaçōes. Lembramos o conjunto de estudos, organizados por Paulo Cardoso e Sofia Gaio, Publicidade e Comunicação Empresarial. Perspectivas e Contributos; o trabalho de Gareth Morgan, Imagens da Organização, entre outros. Relativamente ao empresário, lembramos, também alguns trabalhos de Peter Drucker.

${ }^{4}$ Cfr. J. Esteves Rei, «Da comunicação empresarial na nova concepção de empresa», in Publicidade e Comunicação Empresarial. Perspectivas e Contributos, Porto,2004, p. 228.

5 Belmiro de Azevedo, citado por Ricardo Miranda, expressa esta ideia, da seguinte forma: "Não acreditamos na imagem apenas transmitida através da publicidade. Antes das técnicas de research, dos números de mercado, das estratégias de marketing, a empresa é um ser com personalidade própria. É sobre esta personalidade que ela constrói toda a sua credibilidade», in A Voz das Empresas, Porto, 2002, p. 33.
} 
no consumidor ${ }^{6}$; nesta perspectiva, a identidade pertence à empresa, enquanto a imagem pertence ao público. Por simplista, esta divisão é contestada por outras correntes. A identidade será antes o resultado da interacção que se estabelece entre a empresa e o consumidor, que lhe reconhece um conjunto de características vinculadas ao nome. A imagem, propriamente dita, é um resultado da identidade criada; é uma construção mental do público, abstracta, qualitativa, baseada nos valores da empresa.

Nos nossos dias, falar de criação de imagem implica, necessariamente, recorrer à Comunicação Empresarial. Enquanto domínio do saber, conscientemente desenvolvida para apoio às actividades empresariais, ela acompanhou o desenvolvimento económico da segunda metade do século XX. Disciplina recente, não significa que tenha sido uma criação dos anos após a II Grande Guerra. De facto, enquanto conjunto de técnicas de comunicação que a empresa domina para se dirigir ao público interno (funcionários) e ao público externo (clientes e sociedade, no geral) ${ }^{7}$, a comunicação empresarial já foi praticada, como forma estratégica de afirmação, desde finais do século XIX.

No que respeita à comunicação externa, as empresas criaram logótipos, anúncios publicitários e aquilo que hoje se designa por estacionário: papel de carta, envelopes, cartôes. Umas tornavam-se mais conhecidas do que outras, sem dúvida ${ }^{8}$. Com grande poder intuitivo, construía-se, tal como hoje, um triângulo de comunicação que respondia, em cada um dos seus vértices, às questôes: o que faço? Como comunico o que faço? Como sou considerado pela sociedade? Os empresários geravam novos procedimentos que conduziam à criação da imagem, em torno da actuação, da identidade e da comunicação da sua empresa. Neste conjunto, não deixavam de estar presentes códigos de valores e de ética profissional, abrindo-se à construção de uma cultura própria, em que se integraram preocupaçôes cívicas. Assim podem ser entendidas as diferentes campanhas de solidariedade levadas a feito por empresários, aquando da ocorrência de catástrofes, como cheias ou incêndios, podendo dirigir-se quer à população, quer a outros companheiros de ofício ${ }^{9}$. A actividade empresarial desenvolve-se através da forma como se conhece o mundo exterior e se actua sobre ele; manifesta-se num cenário multifacetado, como demonstra Peter Drucker que chega a concluir que a actividade empresarial diz respeito a todas as actividades dos seres humanos, excepto àquelas que poderíamos chamar mais «existenciais» de que «sociais» ${ }^{10}$.

\footnotetext{
${ }^{6}$ Esta discussão é claramente apresentada por Jorge D. Fernandez Goméz, «La marca: activo estratégico de las organizaciones", in Aproximación a la estructura de la Publicidad..., pp. 34- 83.

${ }^{7}$ J. Esteves Rei, op. cit., pp. 227-237.

${ }^{8}$ Lembramos, a título de exemplo, as estratégias empresariais desenvolvidas na regiāo de Coimbra, Leiria e Aveiro, estudadas por J. M. Amado Mendes, Alda Mourão Filipe e Manuel Ferreira Rodrigues.

${ }^{9}$ É o caso dos empresários leirienses, por exemplo. Cfr. Alda Mourão Filipe, A formação do tecido empresarial da área económica de Leiria, tese doutoramento, policopiada, 2000.

10 Cfr. P. Drucker, Inovação e Gestão uma obra nova concepção de estratégia de empresa, 4.a ed., 1997, p. 43. Todo o capítulo 1 se debruça sobre a evolução das diferentes concepções por que o empresário (o entrepremeur) tem sido perspectivado.
} 
O espírito empreendedor não se alheou da importância da avaliação interna e, principalmente, externa a que a sua acção estava sujeita. Como somos vistos por outrem? É a pergunta que coloca o empresário empenhado em encontrar a diferenciação, face aos seus concorrentes. Ele sabe que a imagem pública da empresa «não se forma apenas mediante comunicações e acçôes específicas e intencionais, mas também através de actuações da empresa.» ${ }^{11}$. Aquilo que se diz e aquilo que se faz deve apresentar uma grande coerência e harmonia.

A imagem empresarial é hoje entendida como "o maior património das organizaçōes» ${ }^{12}$. Mas não é invenção recente: a preocupação em manter um nome limpo acompanha a história do empresário. Por razões sociais, éticas e morais, mas também para ter capacidade para competir no mercado. Um bom nome, uma boa imagem, gera negócios, atrai clientes, facilita parcerias, concede credibilidade e respeito. A Comunicação reconheceu a sua importância, económica e social, e tomou a imagem empresarial como um objecto de estudo. «Ser conhecido», «ser lembrado», «ser preferido» entrou nos sistemas de comunicação de qualquer organização. Nos nossos dias, a Comunicação Empresarial tem obrigatoriamente duplo sentido: ela destina-se a um grupo externo, os potenciais consumidores de um produto, bem ou serviço; destina-se, também, a todos aqueles que, no seu interior, colaboram nas suas actividades. Esta última vertente comunicacional é a mais recente. A necessidade de qualquer empresa dar conhecer ao público o que faz, como faz, quando o faz, porque o faz esteve na origem da criação de meios para comunicar com o exterior.

A publicidade nasceu exactamente da necessidade de a empresa vender, tornando-se «a voz» que espelha verbal e visualmente uma mensagem.

\section{Relação entre a História e a Publicidade}

O recurso à Publicidade, como pretexto para análises parciais sobre a sociedade, não é recente. Aliás, a sedução que produz no consumidor transmite-se facilmente ao estudioso. Daí resultaram abordagens a práticas de consumo entre adolescentes e entre públicos infantis; ao efeito produzido nos comportamentos face ao álcool e ao tabaco; à construção de padrões de beleza; à influência em consumos específicos, como material desportivo e vestuário ${ }^{13}$; à forma como se transmite a masculinidade ${ }^{14}$; a temas mais genéricos ligados à mulher e à criança. Nem todos estes estudos tiveram uma componente histórica. Vieram de áreas como a Educação, a Psicologia, a Sociologia, o Marketing, as Ciências do Desporto, a Publicidade, enquanto área de Comunicação.

${ }^{11}$ Cfr. Fábia Ortega Borges, «Comunicação empresarial integrada», in Paulo Cardoso, op.cit, pp. 241-251.

12 Utilizamos a expressão de Roberto de Castro Neves, um prestigiado consultor de empresas brasileiro,

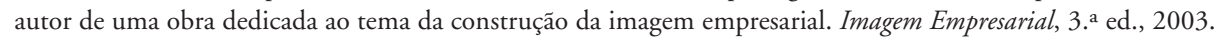

${ }^{13}$ Lembramos os vários trabalhos realizados sobre a Coca-Cola, a Nike, a Benetton, a título de exemplo.

14 Este é o tema do artigo do antropólogo Marko Monteiro, com base na análise de uma revista brasileira, destinada a ambos os sexos: «A Perspectiva do Gênero nos Estudos de Masculinidade: uma análise da revista Ele Ela em 1969» [em linha], UNICAMP, 1997 [consult. 18 de Outubro de 2008], disponível em www: <http://www.artnet.com.br/marko/artigo.html>. 
A historiografia portuguesa já conta com alguns trabalhos que firmaram uma relação com a publicidade. Propomos, neste momento, fazer um levantamento de alguns dos estudos realizados.

No ano de 1946, publicou-se uma obra pioneira no uso da publicidade institucional, com clara finalidade propagandística do Estado Novo. Com muita clareza, A propaganda dos CTT: poderoso factor de aglutinação do Império ${ }^{15}$, dava relevo à função ideológica que assumia a comunicação externa de grandes empresas, como os Correios e Telecomunicações de Portugal. O seu autor, Francisco do Vale Guimarães, associava o poder da mensagem publicitária/propagandística à missão do serviço público, veiculando os valores do próprio regime político.

Já entrara a década de 1960 quando, entre nós, se assistiu à divulgação de novos trabalhos que se centraram na publicidade, enquanto área de comunicação em fase de afirmação, aliada à dimensão histórica. O primeiro deles, publicado em 1964, analisava a publicidade radiofónica; no ano seguinte o interesse manifestava-se pela publicidade aos vinhos portugueses ${ }^{16}$. Apesar da crescente importância assumida pela publicidade, na sociedade portuguesa, que leva mesmo a que se viva a sua "época de ouro», na designação encontrada por Rui Estrela para se referir ao período 1960-197317, segue-se um novo período de abrandamento editorial. Recupera-se, já após a instauração da democracia, com um primeiro trabalho de Regina Tavares da Silva, publicado em 1979, que analisou a imagem das mulheres, construída pela publicidade ${ }^{18}$. Escolhendo uma temática mais abrangente, o estudo realizado por nós e por Maria Isabel Serrão escolheu os anúncios publicados na imprensa local, entre meados do século XIX e inícios do XX, para acompanhar a evolução da sociedade de Leiria ${ }^{19}$. Estávamos em 1988.

Seguiu-se a comemoração do aniversário de uma agência de publicidade internacional, estabelecida em Portugal desde 1927, o Grupo McCann. Em 1992, completara 65 anos de actividade, encontrando-se o pretexto para analisar o trabalho feito e o seu impacto na sociedade portuguesa ${ }^{20}$. A partir de então, sucederam-se os trabalhos de cunho académico que associaram a Publicidade à História. Alguns estudos foram elaborados no âmbito de disciplinas de Seminário, nomeadamente de Património Industrial, da Faculdade de Letras da Universidade de Coimbra. Partiu-se da análise

15 Francisco do Vale Guimarães, A propaganda dos CTT: poderoso factor de aglutinação do Império, Lisboa, Tipografia Severo, 1946.

${ }^{16}$ Estes trabalhos foram publicados na revista Control de Publicid Y Ventas. Cfr. Rui Estrela, A Publicidade no Estado Novo, vol. II, Lisboa, 2004, p. 161.

17 Ibidem, pp. 90-106.

18 Trata-se exactamente deste título: $A$ imagem das mulheres na publicidade, Presidência do Conselho de Ministros, Comissão da Condição Feminina, 1979.

19 Alda Mourão Filipe e Maria Isabel Serrão, «Leiria: imagens da vida urbana através dos anúncios da imprensa local (1854-1910) ", Actas do Colóquio sobre a História de Leiria e da sua Região, realizado em 1988. Foram publicadas pela Câmara Municipal de Leiria, em 1991.

${ }^{20}$ Nuno Cardal, Grupo McCann Portugal: 65 anos de publicidade, Lisboa, Texto Editora, 1994. 
da imprensa escrita, nacional ou regional, de sectores publicitários específicos, como a indústria, no geral, ou a indústria do calçado, em particular ${ }^{21}$.

Mais recentemente, o gás e a electricidade deram origem a dois trabalhos que passaram pelo recurso a cartazes, posters e anúncios - Electricidade e Modernidade: cartazes, posters; e As imagens do Gás: as Companhias Reunidas de Gás e Electricidade e a produção e distribuição de gás em Lisboa, uma publicação da Fundação EDP, em $2005^{22}$. É de salientar, nesta última obra, o capítulo assinado por Paulo Simões Rodrigues, em que, partindo dos cartazes publicitários, faz um percurso comparativo entre a Arte e a Publicidade 23 .

Por esta mesma altura, Rui Estrela, publicou a sua tese de doutoramento em Comunicação, A Publicidade no Estado Novo, em 2 volumes, onde analisou a imagem publicitária e algumas campanhas, entre 1932 e 1973. Como o próprio autor afirma, conhecer a história do período foi a única forma de saber interpretar as funçôes ideológicas e sociais presentes. Só assim foi possível analisar os efeitos produzidos na sociedade de então, para identificar os sinais de abertura a novos valores, veiculados pela mensagem publicitária, como os estéticos e os sociais. Todos lembramos os anúncios que conferiam à mulher novos espaços de convívio, onde centralizava o interesse masculino, partilhando álcool e tabaco.

Ao participar na construção do imaginário comum, com que os indivíduos percepcionam o mundo, a publicidade participa também na construção de realidades culturais e sociais ${ }^{24}$.

O percurso pela actividade científica que, no campo da história, tem recorrido à publicidade, como fonte de informação está sumariamente traçado. Sem ter dado origem a uma volumosa produção científica, não deixou de marcar uma linha de investigação que tenderá a aumentar, face a uma maior consciencialização do papel (de)formador de mentalidades que a publicidade desempenha. A década de 90 marcou o arranque de tal movimento.

Tal como ocorre com linhas de investigação mais recentes, no domínio do social, também o uso da publicidade, como fonte de informação, aproximou da História investigadores que se apresentaram com origens de formação distintas, como a Comunicação, a Sociologia, a Antropologia ou a Gestão. Desses diferentes olhares, resultou o traçar de um caminho multidisciplinar, enriquecido por novos quadros teóricos e metodológicos, com que os historiadores se têm enriquecido.

${ }^{21}$ No contexto académico, só nos é possível referir o conjunto de trabalhos disponíveis para consulta em Institutos ou em Bibliotecas. Compulsámos, para este texto, arquivos e bibliotecas da Universidade de Coimbra.

$22 \mathrm{O}$ primeiro é de autoria de Ana C. Matos, Fernando Faria, Luís Cruz. O segundo é de Maria Helena de Freitas.

23 Paulo Simões Rodrigues, "Entre Arte e Publicidade. A imagem do Gás nos cartazes», op. cit., pp. 195-244.

24 Este é o ponto de partida de Paulo B. Sequeira para analisar o papel desempenhado pela publicidade na sociedade. Cfr. "Consumidor mais consciente. Publicidade que aceita o desafio", in Publicidade e Comunicação Empresaria, pp. 99-118. 


\section{Publicidade como fonte histórica}

O nosso estudo elegeu a publicidade, como fonte histórica ${ }^{25}$. Ler a imagem, com este (novo) estatuto, constitui um desafio metodológico. Sem deixar de considerar as diferenças, ocorre uma aproximação aos autores que têm estudado a fotografia, em perspectiva histórica. Também eles reconhecem na imagem parte da cultura visual de quem produz, mas também de quem vê. Procuram não só encontrar significados para as composições imagéticas, mas também porque se encontram num patamar metodológico mais evoluído, que fornece modelos de organização da informação recolhida a partir das representaçôes impressas na fotografia. O trabalho de Ana Maria Mauad pode ser apontado como um desses modelos, a partir da análise que faz a fotografias publicadas em revistas ilustradas, do Rio de Janeiro, na primeira metade do séc. $\mathrm{XX}^{26}$. Desdobra a imagem em dois níveis de informação: o que respeita ao conteúdo e o que respeita à expressão. Daqui evolui para um conjunto de registos observáveis, traduzidos numa grelha organizativa dos dados registados.

A mensagem publicitária exige este e outros procedimentos, pela associação sistemática da palavra e pelas finalidades que pretende atingir. O registo da informação, a partir do anúncio publicitário envolve, para além de tudo o resto que o torna único, a análise da página em que se apresenta, bem como da dimensão e do espaço ocupado. No que respeita ao texto que completa a mensagem, as palavras requerem que se proceda a análise do conteúdo para reconhecer os discursos da sedução, especificamente publicitários, mas também os ideológicos e os culturais.

Todos os recursos teóricos que nos permitiram esta primeira abordagem ao uso da publicidade, enquanto fonte de informação para a construção do saber histórico, no que respeita directamente à construção da imagem empresarial, vieram de diferentes áreas científicas. Cruzámos a História com a Publicidade, o Marketing, a Comunicação Social, a Sociologia, a Antropologia 27.

Partimos da ideia inicial de que comunicar é uma necessidade sentida por qualquer empresa, em qualquer tempo, em qualquer lugar. Assim, usando a expressão de Ricardo Miranda (2002: 20), a publicidade pode mesmo ser reconhecida como «a voz das empresas». Para a "ouvir com clareza», é incontornável o apoio teórico que permite identificar os distintos níveis de discursos (narrativo, económico, estético, tecnológico, pedagógico), a diversidade de funções e a variedade de expressões (lúdica, sedutora,

25 Entendemos a Publicidade como uma prática complexa, que abarca diversas dimensôes: económica, social, cultural, ideológica, psicológica, estética. É uma disciplina da Comunicação, cuja materialização, a mensagem em si, sintetiza todas as dimensões enunciadas.

26 É também importante o trabalho de Maria Ciavatta, «Educando o trabalhador da grande família da fábrica - a fotografia como fonte histórica", in A leitura de imagens na pesquisa social. História, Comunicação e Educação, S. Paulo, 2004, pp. 37-59.

${ }^{27}$ A interdisciplinaridade de que a publicidade é alvo está patente em algumas colectâneas de estudos que lhe são dedicados. Em 2005, foi publicada uma destas obras, Os Sentidos da Publicidade: Estudos Interdisciplinares, que reuniu o trabalho de especialistas do Núcleo Interdisciplinar de Estudos da Linguagem Publicitária (NIELP), do Departamento de Relações Públicas, Propaganda e Turismo da Escola de Comunicações e Artes da Universidade de São Paulo. Ivan Santo Barbosa (org.), Os Sentidos da Publicidade..., São Paulo, Editora Thomson Pioneira, 2005. 
informativa, espectacular) que o anúncio publicitário pode assumir, no seu todo. Os contextos, em que tais estudos ocorrem, apontam para a sociedade do conhecimento e da informação ${ }^{28}$, tal como o fazem associado à comunicação empresarial ${ }^{29}$, à literatura $^{30}$, à educação $^{31}$.

A reflexão sobre a criação da imagem empresarial, através da publicidade, no âmbito da História, requer algumas premissas:

a) a existência de séries documentais que revelem homogeneidade temporal, institucional ou temática;

b) o conhecimento dos contextos, ao nível da produção e da recepção;

c) o princípio da intertextualidade, pelo reconhecimento da presença de vários «textos» em simultâneo;

d) a mobilização de saberes teóricos e metodológicos que decorrem de diferentes disciplinas sociais, apontando para a multidisciplinaridade.

A publicidade, escolhida como fonte histórica, constitui-se como um documento que nos leva a entendê-la, à semelhança do que ocorre com a fotografia, como «uma medição, como uma produção social, cujo conhecimento não se esgota na aparência imediata da imagem» ${ }^{32}$. O momento da execução, o contexto da produção e da publicação, os espaços da circulação e do consumo da imagem publicitária formam um circuito social, cujo conhecimento é fundamental para a descodificação de todo o simbolismo presente. O documento publicitário não é um objecto isolado, mas integra-se num contexto marcado por quem o produziu, na lógica de construção de um discurso visual, dirigido a um destinatário (público) perfeitamente definido, nas suas características. Produtor e receptor desta mensagem são portadores de olhares culturais e ideológicos que podem ser distintos, alargando o significado do que se pretende transmitir e da informação que, efectivamente, se recolhe.

Em síntese, no nosso entender, a imagem publicitária, à semelhança do que ocorre com outros tipos de imagem, deve ser perspectivada sob quatro ângulos:

28 Cfr. Raul Eguizábal Maza(coord.) La Comunicación Publicitaria. Antecedentes y tendências en la Sociedad de la Información y el Conocimiento, Comunicación Social Ediciones y Publicaciones, Sevilha, 2004 .

${ }^{29}$ Cfr. Ricardo Miranda, A Voz das Empresas, Porto, 2002 e Paulo Ribeiro Cardoso et al Publicidade e Comunicação Empresarial. Perspectivas e Contributos, Edição Universidade Fernando Pessoa, Porto, 2004.

${ }^{30}$ Cfr. Maria José Alonso Seoane, Narrativa de ficción y público en España: los anúncios en la Gaceta y el Diário de Madrid (1808-1819), Editorial Universitatas, Madrid, 2002.

31 Marc Ferro, a propósito do recurso didáctico ao cinema, afirmava numa entrevista: «o saber [hoje] passa necessariamente pela imagem» (Folha de S. Paulo, Separata, 11 de Setembro de 2004, p. 3, citado em A leitura de imagens..., p. 12).

32 Trata-se da visão que é conferida à fotografia, enquanto fonte histórica, mas que aplicamos, exactamente, à imagem publicitária. A autora, Maria Ciavatta, analisou as relaçôes «familiares» estabelecidas entre a fábrica e o operário a partir de fotografias «oficiais» de algumas unidades brasileiras. Trabalha sobre um projecto mais alargado que tem como tema «O mundo do trabalho em imagens» Op. cit., pp. 37-59. 
1. o da produção - ao nível dos diferentes valores da sociedade que a produz;

2. o da recepção - agora ao nível dos valores de quem a recebe. O leitor da imagem visual pode incorporar novos significados culturais, relacionados com o contexto em que se encontra, e que pode diferir do contexto da produção. O que significa que não é um leitor passivo, porque interage com a imagem, atribuindo-lhe valores que se aproximam ou distanciam do seu universo cultural;

3. o do produto - que se revela ao nível da construção de uma narrativa que traduz um tempo e um contexto, apelando aos sentidos e às referências culturais;

4. o da circulação - traçando o percurso da própria imagem publicitária, enquanto instrumento de comunicação.

Palavra e imagem cruzam-se para criar a mensagem. Por vezes, o uso exclusivo de texto conduz à expressão mais eficaz dos valores a transmitir, evitando a efeito distractor da associação de imagem.

Pode falar-se no outro lado da imagem. Os objectos ou os cenários escolhidos propõem uma visão do mundo comprometida com o contexto da sua produção, quer seja político, social, económico, estético, cultural. Estrutura-se uma «visão» no receptor, que se desdobra em realidade e em imaginário, que conduz a um exercício primeiramente estético, guiado por uma orientação política, social, cultural. Podemos lembrar, a título de exemplo, os resultados a que nos conduzem as análises permitidas pela publicidade sobre estudos de géneros: que elementos contém a imagem, de facto? A que imaginário apelam? Que mensagem sublimam? Em que contexto ideológico, cultural são produzidas? Em que ambiente são recebidas? Poder-se-á perceber, ainda, a existência de uma relação de causa/efeito, entre o autor e o «leitor» da imagem. Como escreve Isabel Calado (1994: 121), «não cabe a um simples emissor outorgar o sentido à mensagem, é necessário uma negociação». O que conduz à formulação de uma outra questão, muito associada à finalidade primária, que é dar a conhecer um produto ou serviço: que efeito produz a mensagem? Apresentam-se, assim, diferentes filóes de informação. Para a História, importam os que definem os contextos da produção e os da recepção.

O uso da imagem publicitária, enquanto fonte histórica, requer a utilização de ferramentas metodológicas específicas e respostas a novas questões epistemológicas, que se colocam face à transversalidade com disciplinas que estabeleceram um diálogo muito recente com a História. A imagem não é um objecto disciplinar, por si só, exigindo um tratamento partilhado e cruzado por diferentes áreas do saber.

\section{Estudo de caso: Boletim da Câmara Portuguesa de Comércio e Indústria}

\subsection{A Câmara Portuguesa de Comércio e Indústria}

Como estudo caso, encontramo-nos a iniciar a análise de uma publicação institucional: o Boletim da Câmara Portuguesa de Comércio e Indústria, do Rio de Janeiro, editada entre os anos de 1913 e de 1931. Esta série documental, pela sua dimensão e temporalidade, apresenta-se como uma base de trabalho de grande qualidade e interesse. 
A Câmara Portuguesa de Comércio e Indústria (CPCI) do Rio de Janeiro foi criada, por Decreto, em 16 de Setembro de $1911^{33}$, fruto de um movimento de empresários de origem portuguesa, aí instalados. Para além de procurar facilitar as relações económicas com o Estado português, era encarada como uma necessidade para confirmar o poder económico já atingido por alguns e para apoiar a integração de muitos outros empresários. Era, ainda, tido como um interlocutor privilegiado com as autoridades brasileiras. Acresce, a tudo isto, o facto de se tratar de uma comunidade imigrante, cujo país de origem, em 1912, se apresentava em 6. lugar, entre os países exportadores para o Brasil, «e eram os principais supridores de géneros alimentícios básicos, tais como feijão, bacalhau, azeites, vinhos, vegetais e milho, bem como de tecidos da manufactura portuguesa e matéria-prima», nas palavras de Eulália Lobo (2001: 33). Como a generalidade das associações profissionais, representava também uma comunidade de interesses ${ }^{34}$, patente nos Estatutos e na sua prática filantrópica e social.

Pelo acervo fotográfico, aliado às secçōes noticiosas das suas publicações, podemos constatar que foi, também, criando espaços de sociabilidade para uma elite imigrante, à medida que se impunha numa rede de relações com as instâncias do poder (político, social, cultural). Ser sócio da CPCI significava ter um «ancoradouro», socialmente reconhecido. Podia significar solidariedade e ajuda em tempos difíceis. Podia significar a partilha de um espaço e de uma identidade que prolongava o espaço português no Brasil.

É a mais antiga das Câmaras Portuguesas de Comércio e Indústria, não só no Brasil, como no resto do mundo ${ }^{35}$. Em 1911, a jovem República Portuguesa apoiava a criação destas associações por se tratar, sem dúvida, de estruturas prestigiantes para a sua própria afirmação no estrangeiro. O significado da fundação da CPCI, no início da década de 1910, ganha maior relevo por antecipar as suas congéneres, na praça do Rio de Janeiro: lembramos a Câmara Alemã, fundada em 1918, e a Câmara Italiana, fundada em 1950.

Nos seus primeiros Estatutos, divulgados em anexo ao Decreto de criação, dispunha-se, na alínea k) do art. I, que «Publicará um boletim em que se registem periodicamente todas as informações, notícias e estatísticas que interessem aos fins da instituição e, inclusivamente, artigos, estudos e quaisquer trabalhos de educação comercial e industrial úteis aos associados e ao comércio em geral». Ficavam traçados os objectivos que se pretendiam alcançar com a publicação que viesse a ser criada. Ao longo do ano de 1912, procuraram-se as condições para que o Boletim pudesse ser concretizado. E assim surge o primeiro número, em Janeiro de 1913, com o artigo «Abrindo", assinado por Fernão Botto Machado, então cônsul de Portugal no Rio de

33 O decreto de criação aprovava, em simultâneo, os Estatutos da CPCI. Era assinado pelo Presidente Arriaga e pelo Ministro do Fomento, Sidónio Pais.

34 Émile Durkheim, A Divisão do Trabalho Social, vol. I, Lisboa, Editorial Presença, 1989, p. 19.

35 Cfr. Heloisa Paulo, «Entre republicanos e conservadores: a Câmara Portuguesa de Comércio e Indústria do Rio de Janeiro", Estudos do Século XX, n.o 4, 2004, pp. 369-390. Em Paris, seria criada em 1918. 
Janeiro $^{36}$. Iniciava-se uma publicação institucional, que irá prolongar-se por quase 20 anos. Após 5 anos de interrupção, a CPCI retomará uma publicação mensal, próxima do Boletim, em 1936, através da Revista da Câmara Portuguesa de Comércio e Indústria.

Não é o momento de analisar o conteúdo da publicação, apesar de rapidamente se identificarem movimentos que acompanham as alterações políticas vividas deste lado do Atlântico, como já identificou Heloisa Paulo, ao reconhecer em alguns dos sócios figuras ligadas à oposição ao Estado Novo ${ }^{37}$. Interessa-nos focar a mensagem publicitária transmitida pelo primeiro órgão da CPCI, para perceber a forma como evoluiu, por esta via, a imagem empresarial da comunidade portuguesa que se transmitia aos leitores, em território brasileiro.

\subsection{A publicidade do Boletim: metodologia de trabalho}

A metodologia utilizada para proceder à análise de mensagens publicitárias pode assumir diversas soluçôes, um pouco na linha do que apresentam os autores que suportam a sua investigação em fotografias, e que já foram lembrados anteriormente. Não foi incorporado o método aplicado por Renato Seixas (2006: 234-381) a anúncios sul-americanos, por se tratar de uma série com características bem diversas da nossa (selecção de alguns anúncios de diferentes países do continente), cumprindo finalidades distintas (procura de elementos de uma identidade cultural sul americana), descrevendo a mensagem para analisar o seu conteúdo imagético e linguístico ${ }^{38}$.

Apresenta-se uma proposta metodológica, que ainda se encontra em fase experimental, sujeita a alterações que permitam agilizar, principalmente, o processo de anotação de registos.

Partindo de uma série homogénea, pela utilização de um único órgão de publicação, a primeira etapa pressupóe um trabalho teórico que se torne alicerce para o conhecimento dos contextos de produção, de recepção e de circulação do anúncio publicitário. Concretizando, para este estudo especificamente, deverá ser compreendida a forma como se instalou uma comunidade imigrante, com afinidades culturais, mas também sofrendo grande resistência por parte de alguns sectores. O lugar do imigrante português coloca-se no centro do debate, antigo, mas ainda muito do interesse de

36 A colaboração de Botto Machado aponta para a estreita relação que, nestes primeiros anos a CPCI mantém com o Governo da República Portuguesa, com o movimento republicano e, a esclarecer, com a maçonaria. Deputado e diplomata, Fernão Botto Machado foi, também, autodidacta, solicitador, participante na sublevação do 5 de Outubro de 1910. Dirigiu e colaborou em inúmeros jornais. Na carreira diplomática, é indigitado Ministro na República na Argentina (1912), mas não tendo sido possível ocupar o cargo, foi nomeado Cônsul Geral no Rio de Janeiro (1912) (Almanaque Republicano [em linha], [consultado em 23 de Maio de 2008], disponível em www: <http://arepublicano.blogspot.com>).

37 Através de algumas das personalidades estudadas em Aqui também é Portugal. A colónia Portuguesa do Brasil e o salazarismo (2000) é possível acompanhar a forma como a implantação do Estado Novo é vivida no Brasil. Para a CPCI, em particular, vide Heloisa Paulo, op. cit., pp. 369-390.

38 Renato Braz Oliveira de Seixas, Identidade cultural da América Latina nas mensagens publicitárias - aspectos dos processos de integração cultural e global, S. Paulo, 2006. 
várias áreas científicas, sobre a construção identitária da sociedade carioca. A óptica das abordagens acarreta extremos: desde a perspectiva do lugar inquestionável do imigrante português no desenvolvimento da economia e do espaço urbano do Rio de Janeiro, até à construção do português-anedota, que decorre da ideia de atraso, de níveis de cultura e de escolaridade muito baixos, que o remete para os escalóes inferiores das categorias socioprofissionais, nos últimos anos do século XIX e nos primeiros do XX. Numa sociedade que carregava o estigma de capital de antiga colónia, existiam marcas de repulsa ao passado. Para além de tudo o que ficou expresso, o Brasil representa uma identidade multicultural, já muito evidente na década de 1910 e que se torna mais complexa com a chegada de novas ondas de imigração. Um processo que ocorre em toda a América Latina, apontando para a sociedade global, antes da globalização. Estes pressupostos estiveram na base de uma tese de doutoramento que questionava se, a existir uma identidade cultural genuinamente latino-americana, os elementos de identificação estariam presentes nas mensagens publicitárias ${ }^{39}$. Necessitamos, igualmente, conhecer a realidade empresarial do Brasil, no geral, e do Rio de Janeiro, em particular, de forma a compreender em pleno a actuação da Câmara Portuguesa de Comércio e Indústria e da classe que ela representa. Finalmente, será crucial compreender os diferentes valores da sociedade que produziu e recebeu as mensagens publicitárias do Boletim.

Assim entenderemos o produto, isto é, o anúncio em si mesmo, enquanto instrumento de comunicação que apela aos sentidos, criando e satisfazendo necessidades de consumo.

Partimos para a segunda etapa, analisando a evolução quantitativa, que aponta para períodos específicos do mercado e/ou da vida da CPCI, aos quais se deve dar uma atenção especial. Digamos, que se deve entender como uma primeira chamada de atenção para conjunturas, já identificadas previamente ou a exigir uma análise específica. Isto é, deve-se encontrar resposta à pergunta: o que aconteceu? A variação do volume de anúncios publicados no Boletim apontou, claramente, para o reflexo de conjunturas internacionais e a forma como reagiu a comunidade de sócios. Alterou-se o número de mensagens publicitárias em períodos como seja o da I Grande Guerra, da crise financeira e política da República Portuguesa (com um aumento considerável em 1927 e em 1928), da crise de 1929 e, finalmente, do caminho para a consolidação do novo regime em Portugal (1931 apresenta um número muito acima do verificado nos anos anteriores).

A terceira etapa corresponde à «leitura qualitativa» do conjunto que o acervo nos proporciona. Diríamos que é o momento de nos relacionarmos afectivamente com a fonte. Na generalidade, apreendem-se as características dos anúncios publicitários: dimensão, utilização de cor, tipo de imagem, extensão do texto, inclusão de filetes, composição estética, recursos técnicos, tipo e dimensão de letras. Daqui, cada anúncio passará a valer por si: entramos na quarta etapa. Corresponde à análise e descrição da mensagem publicitária, em si mesma, e da história dos recursos gráficos que a serviam, pois vão mudando com o tempo. É antecedida pela construção de um ficheiro, numa folha de cálculo, preparado para receber as anotações relevantes. Foram escolhidos

39 Renato Braz Oliveira de Seixas, op. cit. 
itens que se adequaram às necessidades de análise da presente série documental, de forma a não deixar de lado informação que fosse relevante, no seu conjunto, para conhecer a evolução da publicidade em si, dos contextos de produção e de recepção da mensagem, da entidade responsável pela publicação, a Câmara de Comércio e Indústria do Rio de Janeiro.

Cada anúncio publicitário é identificado pelas suas características externas:

Ano

Mês

Entidade responsável pelo anúncio

O que se publicita (produto/bem/serviço)

Tipo de negócio

Sector económico em que se enquadra

Frequência de publicação ao longo do ano

Seguidamente, passa-se às características internas. Neste domínio, considera-se a forma e o conteúdo. Assim, no que respeita ao primeiro grupo, o da forma, serão apreciados os seguintes aspectos:

Número e situação de página (frente/verso)

Dimensão atingida (células ocupadas, partindo da divisão da página em 2 colunas e 6 linhas, de acordo com o modelo de paginação da revista)

Técnica utilizada (linóleo, zincogravura)

Utilização de cor (sem cor/com cor)

Composição apresentada (texto/imagem/ambos)

Situação face à imagem (desenho/fotografia/misto)

Dimensão do texto (curto/longo)

Tomando em consideração o conteúdo da mensagem publicitária, procede-se aos registos de:

Elementos dominantes na composição (texto; figura; objecto; paisagem)

Especificação do elemento dominante

Figuração (pessoas; animais; edifícios; objectos, filete)

Detalhe de Figuração: Feminino, Masculino; Criança, Adulto; Edifício; Fábrica, Escritório; Animal; Objecto, Filete

Situação expressa (trabalho, lazer, quotidiano)

Especificação da situação

Palavra: palavra-chave; repetição de vocábulos; destaques

Mensagem: a ideia que é expressa

Os resultados a que vão conduzir os dados assim trabalhados ainda não estão disponíveis, pelo facto de se tratar de um trabalho em curso. Neste trajecto, já é clara a preocupação em construir uma imagem credível e ganhadora por parte de alguns anunciantes, sócios da Câmara de Comércio e Indústria do Rio de Janeiro. 


\section{Em conclusão}

A história empresarial, como área de divulgação recente, entre nós, tem revelado novos filóes de pesquisa, acompanhando o evoluir do conceito de «empresa» e de «empresário».

A procura de fontes documentais que deixem de se confinar aos arquivos de empresa e aos registos notariais tornou-se uma necessidade, um desafio e uma prática para os investigadores. Pela nossa parte, elegemos a publicidade como fonte histórica. Através dela, procuramos obter uma outra perspectiva sobre estratégias de criação de um nome, de uma identidade e de uma imagem no mundo empresarial. Tudo isto decorre em momentos políticos precisos, que desenham a evolução dos mercados e a criação de novos públicos. Esta constatação tem acarretado o atenuar de fronteiras do saber social. Para encontrar resposta para os novos desafios do conhecimento, o percurso da história empresarial passa pela Comunicação, pelo Marketing, pela Gestão, pelas Relações Públicas, pela Sociologia.

Ler a imagem com o estatuto de fonte de informação para a História, não é uma iniciativa inédita, como vimos. A variedade de temáticas em que a publicidade tem sido utilizada, associada à diversidade de órgãos de comunicação seleccionados, conduziu a processos metodológicos adequados a cada caso, em particular. A necessidade de encontrar procedimentos de recolha e de tratamento de informação obtida, continua a constituir-se, portanto, como um desafio metodológico.

O Boletim da Câmara Portuguesa de Comércio e Indústria, do Rio de Janeiro, publicado entre 1913 e 1931, foi o ponto de partida. Os quase 20 anos em análise proporcionaram alterações sociais, políticas e culturais profundas. A publicidade demonstrou as mudanças que ocorreram à escala mundial, mas também à dimensão regional. Tratando-se de uma publicação da responsabilidade de uma comunidade de portugueses imigrados, com grande necessidade de reconhecimento e credibilidade locais, a publicidade inserida no Boletim sintetizou um estilo de vida, com padrões que faziam a ligação entre o Brasil, onde se fazia sentir a influência dos EUA, e Portugal, que se ia isolando do resto do mundo.

\section{BIBLIOGRAFIA}

Alonso SeOAne, Maria José (2002) - Narrativa de ficción y público en España: los anúncios en la Gaceta y el Diário de Madrid (1808-1819), Madrid, Editorial Universitatas.

BASTIEN, Carlos (2004) - "A história empresarial em Portugal: um balanço da conjuntura teórica», Estudos do Século $X X$, n. $^{\circ}$ 4, «Empresas e Empresários», Coimbra, Ceis 20, pp. 41-58.

CAlado, Isabel (1994) - A utilização educativa das imagens, Porto, Porto Editora.

Cardoso, Paulo Ribeiro; GaIo, Sofia Nora (orgs.) (2004) - Publicidade e Comunicação Empresarial. Perspectivas e Contributos, Porto, Edição Universidade Fernando Pessoa.

Ciavatta, Maria; Alves, Nilda (orgs.) (2004) - A Leitura de Imagens e a Pesquisa Social. História, Comunicaçāo e Educação, São Paulo, Cortez Editora.

FERNÁNDEZ GÓMEZ, Jorge D. (coord.) (2005) - Aproximación a la estructura de la Publicidad, Desarrollo y funciones da la actividad publicitaria, Sevilha, Comunicación Social Ediciones y Publicaciones. 
FreitAS Filho, Almir Pita (2002) - «A colónia portuguesa na composição empresarial da cidade do Rio de Janeiro no final do século XIX e início do XX", Os Lusiadas na aventura do Rio Moderno, (org. Carlos Lessa), Rio de Janeiro, Editora Record, pp. 163-197.

GalHARDO, Andreia (2002) - A sedução no anúncio publicitário. Expressão lúdica e espectacular da mensagem, Porto, Edição Universidade Fernando Pessoa.

GRUNIG, Blanche (1998) - Les mots de la publicité, Paris, CNRS Éditions.

GUARINELLO, Norberto Luiz (2004) - «História científica, história contemporânea e história cotidiana», Revista Brasileira de História, vol. 24, n. ${ }^{\circ}$ 48, São Paulo.

LOBO, Eulália (2001) - Imigração Portuguesa no Brasil, S. Paulo, Editora HUCITEC.

MAZA, Raul Eguizábal (coord.) (2004) - La Comunicación Publicitaria. Antecedentes y tendências en la Sociedad de la Información y el Conocimiento, Sevilha, Comunicación Social Ediciones y Publicaciones.

MENDES, José M. Amado (2004) - «Elite empresarial e História das empresas: em busca de uma imagem de marca, 1924-2003», Estudos do Século XX, n. ${ }^{\circ} 4$, «Empresas e Empresários», Coimbra, CEIS20, pp. 17-39.

Miranda, Ricardo (2002) - A Voz das Empresas, Porto, Porto Editora.

Morgan, Gareth (2007) - Imagens da Organização, S. Paulo, Editora Atlas.

Neves, Roberto de Castro (2003) - Imagem Empresarial, 3a edição, Rio de Janeiro, Mauad Editora.

PAUlo, Heloisa - «Entre republicanos e conservadores: a Câmara Portuguesa de Comércio e Indústria do Rio de Janeiro», Estudos do Século XX, «Empresas e Empresários», n. o 4, 2004, pp. 369-390.

SEIXAS, Renato Braz Oliveira de (2006), Identidade cultural da América Latina nas mensagens publicitárias - aspectos dos processos de integração cultural e global, 2 volumes, tese de doutoramento apresentada ao Programa de Integração da América Latina, Universidade de São Paulo. 
